\title{
Education for Sustainability in Newark's Public Schools Reconsidered: Ecological Problems within American Racial Domination
}

\author{
Irma Febriyanti ${ }^{1}$, Ida Rochani Adi $^{2}$, Heribertus Jaka Triyana ${ }^{3}$ \\ \{irma.febriyanti@mail.ugm.ac.id ${ }^{1}$; irma.febriyanti@unipma.ac.id ${ }^{1}$,idaadi@ugm.ac.id², \\ jaka.triyana@mail.ugm.ac.id ${ }^{3}$ \} \\ 1,2,3 Universitas Gadjah Mada, Indonesia
}

\begin{abstract}
Sustainability Development Goals (SDG) is one of United Nations' program to achieve sustainability in both cultural and natural ecosystem. Sustainability in education, as one of the goals in SDG aims to provide equal access to education for all children across race and social class. In United States of America, SDG USA seeks to improve social mobility, educational access and sustainable environmental development. This paper is on the opinion that sustainability development in USA, especially in educational field should be reconsidered based on case study on Newark, New Jersey. The neighborhood which is dominated by African-American suffers from disproportionate access to education as the whites has more opportunity to achieve higher education. Responding to this phenomenon, this paper applies social ecological approach as is theorized by Murray Bookchin. Bookchin argues that ecological problems cannot be understood, let alone solved without first resolve the question of class, race, and gender as the root. In other word, human domination of other human remains as important as human domination of the environment. The analysis is conducted using the discourse analysis framework as theorized by Van Dijk (2005). This paper concludes that SDG USA concerning sustainable development should address the more pressing issue related to racism.
\end{abstract}

Keywords: Sustainable Development Goals (SDG), African-American, Social Ecology

\section{Introduction}

The world perceives America as a democratic nation, founded upon the pluralistic spirit of its diverse encompassing ethnicities. America is considered as 'the first global, cosmopolitan polity.... a cosmopolitan federation of foreign cultures...a world federation in miniatures." $[1]$ This aforementioned views highlighted how America is considered as a stark example of successful multi-ethnic society. Further scrutinize upon the layers that constitute American intercultural society reveal a more distressing outlook. The interaction among the multi ethnicities of the United States is marred with history of racial segregation, discrimination, and forced assimilation into the dominant white, Anglo-Saxon Protestant culture. [2], [3] Although large steps have been undertaken in the minorities' struggle for equal right, such as such as the abolishment of draconian Jim Crow Laws and the successful Civil Rights Movements in the 1960 's, the minorities remain struggling for equality.

As an ethnic minority in the United States, African-American remain prone of being subjected into segregation, either in form of physical abuse, verbal harassment, or a more subtle marginalization. The African-Americans are subjected in a systematic and structural violence which hinders the achievement of basic human rights such as housing, higher 
education, career advancement. "A violent structure impedes the development of the group and the self through a structure which is generally invisible." [4] Such invisible structure is imbedded within the environment that the African-American is forced to reside into. In Galtung's words, "the violence is built into the structure and consequently as unequal life changes [5] The African-American are being segregated into poor residential areas with limited access to amenities and to higher education. As early as the late $19^{\text {th }}$ century, Du Bois' research of Philadelphia Negro (1899) has underlined the effect of housing conditions on the health, character, and the social environment of Philadelphia's black citizens. Expanding on Du Bios' seminal work, Robert Bullard foregrounds discriminatory policy based on racial lines, he explores how environmental racism refers into any policy, practice, or directive that differentially affects or disadvantages (whether intended or unintended) individuals, groups, or communities based on race or color [6]

The continuation of environmental racism that perpetuate American society hinders the goals of sustainable development which can be charted through the Sustainable Development Goals of the United States. (SDGUSA) [7] A notable case study in the state of New Jersey that foregrounds a contradiction between the high overall score and how this state deals with the prevailing racial discrimination. Although at the first glance the overall score of 52, 7 (ranks 14 among the 51 states) indicates a modern and forward-looking state, a glaring contradiction exists in the Reduced Inequality Goal in which this state ranks in the bottom three. (indicates) New Jersey (high rank of racism in residential segregation, incarceration rates, educational attainment and 'pollution burden'. [8] This exposition underlines how environmental racism that discriminate based on racial lines remain an issue in the state of New Jersey.

This paper focuses upon the African-American right to education in Newark, New Jersey which is hindered by the continuation of institutionalized racism. Although historically this city plays an important role in African-American resistance by hosting the first-ever Black Power Conference, this is marred by racism which remains an integral element of the Newark community. [9] Education in Newark remains demarcated upon racial division, in which the Black students suffer from lack of access to higher education. As stated by Rothstein,

Schools that the most disadvantaged Black children attend are segregated because they are located in segregated high poverty neighborhoods, far distant from truly middle-class neighborhoods. Living in such high-poverty neighborhoods for multiple generations adds an additional barrier to achievement, and multigenerational segregated poverty characterizes many African American children today. [10]

The prior assertion situates the continuing presence of institutionalized racism in educational field in Newark, New Jersey. Years after the successful Civil Right Movements, education in Newark remain disproportionately biased toward the white students and discriminate the African-American students. Taking the situation of Newark, New Jersey as a case study, this paper proposes that sustainability, especially as it is addressed in SDG USA cannot be achieved without firstly addressing racial inequality. 


\section{Theoretical Background}

This present study applies social ecology as the theoretical framework, this paradigm is based on the conviction that the situation concerning ecological problems is based on deep seated social problems. This perspective believes that aspects related to sustainability, as is stated in the SDG USA cannot be fully achieved without consideration of the racialized issues as the underlying roots of the problems. The basic tenet of social ecology, as is addressed by Murray Bookchin is exemplified in "the very notion of the domination of nature by man stems from the very real domination of human by human" - [11] (Bookchin, 65). Social ecology condemns hierarchical social systems based on class status and racial lines as a society marked by inequality, hierarchies and exploitation will trend its environment as its members treat each other. [12]

Social ecology argues how premises concerning relationship between human and nature originated from the hierarchical class system that differentiate humanity based on racial lines. Bookchin posits several questions that deal with the interconnection between domination of nature by human and domination of human by human:

"How did a divisive, indeed, seemingly combative, relationship between humanity and nature emerge? What were the institutionalized forms and ideologies that rendered this conflict possible?" [13]

Throughout his argumentation, Bookchin proposes a further scrutinize of anthropocentric point of view which treats nature as merely properties. He argues how this paradigm stems from the exploitation of the 'lesser' human by the 'superior human' in order to harness nature through slavery, serfdom, or forced works. The ideology of dominating the natural world, he has long maintained, is an anthropomorphic projection of human social domination onto the natural world. [14] It could only have stemmed historically from the domination of human by human, and not the other way around. Social ecology, as underlined by Bookchin's theorization criticizes the narrow-centric bias of deep ecology movement which asserting equality upon all species and disregarding the underlying premises. "Deep ecology' essential overlooks that profound social differences that divide human from human, poor and rich, women and men, black and white, oppressed and oppressor into a biological lump called 'humanity.' [15] In other word, deep ecological movement disregards the complexities of ethnicities within humanity.

\section{Research Method}

This research is conducted through discourse analysis framework in analyzing online media news as proposed by Van Dijk (2005). Van Dijk argues on the distinction of media textual messages as a 'specific types of text and talks' from the audiovisual forms of discourse in television, film, and radio discourse. [16] In analyzing the continuation of institutionalized racism in Newark, the data is collected from several major online news sources in the United States (www.chalkbeat.org/ ;//www.tapinto.net ; theatlantic.com ; and //www.theroot.com) that foregrounds the lingering presence of segregation. Moreover, several academic articles, prior researches and the survey taken from American census bureau is positioned as secondary data. The analysis follows Van Dijk's schemata on discourse analysis by interrelating the 'textual elements', or in terms of their structures at various levels of description and the 'social-cultural or historical contexts on the other hand". The scheme is articulated as follows news reports follow a hierarchical schema, consisting of such conventional categories as 
Headline, Lead (together forming the Summary), Main Events, Context, History (together forming the Background category) Verbal Reactions, and Comments [17].

In line with the interdisciplinary nature of discourse analysis, this paper relates the textual analysis of online news articles with the Post-Nationalist American Studies paradigm. The situation faced by the Newark African-American community runs parallel with the shifting focus within American Studies into Post-Nationalist which devotes central concern to the marginalization of the non-white citizens. As proposed by Rowe, Post-Nationalist American Studies takes into account "the many different and constantly changing communities that constitute the United States" [18] instead of a holistic view of singular American identity.

\section{Result and Discussion}

This research exemplifies the continuation of institutionalized racism in Newark, New Jersey by elaborating several cases that restrict African-American's right to education. As elaborated in the SDG USA point Reduced Inequality Goals, racism remains a central unsolved problem in present day Newark. In many ways, the institutionalized racism resembles previous state of Separate but equal, enforced by Jim Craws laws that segregate educational system by demarcating black schools and white schools. Brown and Beckett argue how the enforcement of supposedly equal educational system actually eliminate the rich tradition of Blacks education since the slavery era and forced them to abide in the Whites' educational policy. [19] While in theory each student now has equal right to education in Newark, the situation remains disproportionately biased for the white students' benefit.

Segregation within educational system in Newark is intertwined with the historical background that separated African-American residential area from the dominant Whites. The disparities of economic powers and social status forced the African-American community to reside in poor residential areas. Massey and Denton (1989) explore that while this marginalization affects all ethnic minorities in the U.S, what they theorize as hyper segregation, the African-American is the most impacted group. [20] A research by Mumford Center concerning ethnical diversity in various neighborhood in the US (2001) extrapolate Newark's situation as one of the most segregated cities in the nation. Their finding concludes that the black population in Newark suffers from high isolation rate -how geographically isolated different groups are from one another- which indicates how the black community in Newark is ostracized and having limited opportunity to interact across racial boundaries. [21] The African-American's social mobility is further hindered by the demarcation between 'white and black concentration'

Large parts of New Jersey, generally but not exclusively suburban, remains area of 'White concentrations'. This in turn has given rise to the concentration of Blacks and other people of color to a relatively limited number of disadvantaged urban, older suburban, and geographically constricted areas. [22]

The continuing policy of segregation in Newark hinders the African-American right of education by limiting the availability of school to Black students. The segregated housings lead to segregated schools which means that education policy is constrained by housing policy. The door of higher educational system in Newark, especially the public high school remain closed to the African American community. The data taken from Newark Public School Summaries Fall 2017 foreground the disproportionate number of Black Students who attend higher ranking school. [23] Three of the most prestigious high schools, Wilson Avenue, Ann Street Schools, and Lafayette Street has less than 2\% black students who enroll. 
The inequality within one elite high school, Science Park School is contextualized in an online news article, entitled "Racial Tension flare in Newark's elite Science Park High School amid debate over admissions policies. As proposed by Van Dijk's schemata on news articles, both the aforementioned headline and the lead "For months, a racially charged debate has been raging behind the scenes at Science Park High School about how one of Newark's most elite schools selects its students." Together with the lead, the headline expresses the most important information of the text and the summary of the report. The subsequent schematic organization, referred as the Main Events further contextualizes the main problem concerning the bias of student admission test.

Science Park is the district's most popular public high school, a selective magnet school that was the top choice for students' applying to high school last year. But the National Blue Ribbon School's enrollment does not reflect the district's. A disproportionately small share of its students are black, and disproportionately large share are white. [24]

This exposition of racism in the Main Events is followed by the context and history which forms the Background category. It can be inferred how the Science Park case is a reflection of the wider presence of institutionalized racism in Newark which segregate the access of higher education among racial lines. The admission test is purely based on state test score, in which African-American students who graduate from lower quality school is distinctively disadvantaged.

As previously illustrated, the Science Park's policy underlines how education in Newark remain divided upon racial lines, in which the privileged ethnic remains the Whites and the Blacks kept subjected into many disadvantages in housing, economic disparities, educational attainment which restrain their right to education. This phenomenon becomes a major concern in another online news article with the headline "State to Answer Lawsuit Seeking to Integrate NJ Schools by Friday". In their lead paragraphs, Woolston, Panico and Haydon underlines the struggle for desegregation in several New Jersey districts, Newark, Camden and New Brunswick. Within the Main Events, these writers conceptualize how segregated schools in New Jersey has a long and entrenched apparatus of white domination. As summarized in the preceding section. New Jersey is one of the hypersegregated state in the Union that hinders the opportunity for social mobility across social demarcation. It is quoted how, Such a lawsuit drives directly into New Jersey's core, a practice of generation in which mostly white children have the opportunity to attend better schools, with better staff, in better environment. And for the others? Old often outdated schools, with lackluster results, in the state's poorer communities. [25]

The existence of environmental racism, in which the Black community is more prone to environmental hazard compared to the Whites is also experienced by the African-American community in Newark. Pollution becomes a central issue, extrapolated by Newark's position as a major hub for shipping, air and rail. As indicated by SDG USA Goal 10 [8], the people of color's exposure to toxic pollution rank in the bottom three among the states foregrounds the lingering presence of environmental racism as the African-Americans are the most affected ethnic group. African-American children have more exposure toward the air pollution, nearly all public school nurses identify asthma as a major health problem for Newark children, and more than 76 kids are admitted to the hospital with asthma each month.[26] A recent environmental hazard, evidence of lead contaminated drinking water in Newark Public School asserts the still-ongoing struggle for environmental justice in Newark. Based on the information by Newark Public Schools system, around half (30) schools from 66 Public School had issues with elevated lead levels in water. The dilapidated state of Newark water infrastructure concerns the current mayor, Ras J. Baraka to write a letter for U.S President, 
Donald Trump, bringing forward the urgency of solving water contamination. The headline, "Newark Mayor to Trump: Forget the Wall ! Our City's Water Has 'Dangerously High' Levels of Lead" captures the macabre situation faced by the African-American community in Newark. The Main Events further explores how I want to bring your attention to a true emergency that puts millions of our citizens at risk: The decaying infrastructure of our water systems which has created a crisis in Newark, the State of New Jersey and across America. Dangerously high levels of lead are entering homes and our children's blood through lead service lines despite the fact that any level of lead can damage the developing brains of young children.” [11]

As this paper has asserted, sustainability cannot be achieved without firstly addressing social inequality, and the necessary steps forwards sustainability, as seen in SDG USA is empowerment of the African-American community. Having subjected into institutionalized racism that segregate their residential area, educational option and much more prone to being exposed to environmental hazard, the African American's agency is restrained. Bookchin foregrounds how the existence of a hierarchical class system will always lead into 'domination of human by human'. Based on ecological concept of equality among all species, Bookchin proposes anarchism as a natural partner to ecology, similar with how ecology consists of diverse biotic and abiotic component of equal value he argues for abolishment of social class and creating a balanced community.

The long-term solution to the ecological crises is a fundamental shift in how we organize society, a new politics based on face-to-face democracy, neighborhood assemblies and the dissolution of hierarchy'." [27]

It can be foregrounded how Bookchin stresses the necessity of total societal breakdown so that a new order can be established. Different with Bookchin, this present study advocates for reform within the system itself through the empowerment of the African-Americans. Environmental justice movement has underlined the lack of political power of ethnic minority plays a pivotal role in the failure of addressing ecological problems. As seen in Baraka's frantic request to the U.S president, the national government's lack of urgency concerning the lead contamination in Newark should be addressed by empowerment in state/federal levels. Several examples are the Newark Promise plan which emphasized local control of the staterun district and infrastructure upgrade and NJEJA (New Jersey Environmental Justice Alliance) in which the key tenet is "to create healthy, sustainable and just communities by eliminating environmental injustices in low income and communities of color." [28]. To conclude, the African-American community in Newark should have more political power to articulate their resistance against the institutionalized racism that segregate them.

\section{Conclusion}

To reiterate, this paper affirms that ecological sustainability cannot be achieved without firstly addressing the question of racial inequality. The situation in Newark, New Jersey exemplifies this argument especially on how this state deals with Sustainability Development Goals (SDG USA). The prevalence of racism becomes an unsolved issue, as seen in the Reduced Inequality Index. Racial demarcation between the whites and the African-Americans still persists, the African-American community in Newark are being subjected into segregation in housing, access to higher education, and exposure into environmental hazards. Viewed through Bookchin's paradigm, the root of this problem is hierarchical structure that legitimize 'domination by human by human'. While this paper affirms with the necessity of eliminating 
hierarchical status, this present study is on the opinion that empowerment of ethnic minority is a possible solution instead of abolishing the system altogether. Increasing political powers, awareness of ecological problems, and greater freedom in state/federal levels are several examples on tackling the entrenched institutionalized racism within American society.

\section{Acknowledgement}

This research is sponsored by Universitas Gadjah Mada Recognisi Tugas Akhir (RTA). This writer sends her gratitude for the insights and contribution done by her supervisors, Prof. Dr. Ida Rochani Adi, S.U and Dr. Heribertus Jaka Triyana, S.H. LL.M., MA during the process of writing this article.

\section{References}

[1] G. Jusdanis, The necessary nation. Princeton University Press, 2011.

[2] A. Hornsby, D. P. Aldridge, and A. M. Hornsby, A companion to African American history. Wiley Online Library, 2005.

[3] J. Sennie, Critical Approaches to Ethnic American Literature. New York: Rodopi, 2007.

[4] W. Graf, G. Kramer, and A. Nicolescou, "Counselling and training for conflict transformation and peace-building," in Handbook of peace and conflict studies, vol. 123, no. 142, ROUTLEDGE in association with GSE Research, 2007, pp. 123-142.

[5] J. Galtung, "Violence, peace, and peace research," J. Peace Res., vol. 6, no. 3, pp. 167-191, 1969.

[6] R. D. Bullard, "Dumping in Dixie: race, class, and environmental quality 3rd ed." San Francisco (CA): Westview Press, 2000.

[7] "Sustainable Development Goals USA.” [Online]. Available: https://www.sdgusa.org.

[8] "Sustainable Development Report of the United States 2018." [Online]. Available: https://sdgdata.sdgusa.org/\#/SDG/10/NJ.

[9] W. M. Phillips, "Educational policy, community participation, and race," J. Negro Educ., vol. 44, no. 3, pp. 257-267, 1975.

[10] R. Rothstein, "The racial achievement gap, segregated schools, and segregated neighborhoods: A constitutional insult," Race Soc. Probl., vol. 7, no. 1, pp. 21-30, 2015.

[11] M. Bookchin, The ecology of freedom. New Dimensions Foundation, 1982.

[12] M. Bookchin, "Remaking society: Pathways to a green future," People, penguins Plast. trees. Basic issues Environ. Ethics. Second Ed. Belmont Wadsworth, pp. 227233, 1995.

[13] M. Bookchin, "Society and ecology," Debating Earth Environ. Polit. Read., pp. 415428, 1998.

[14] J. Biehl and M. Bookchin, The Murray Bookchin Reader. Black Rose Books Ltd., 1999.

[15] M. Bookchin, "The Crisis in the ecology movement," Green Perspect. a Left Green Period., vol. 6, pp. 1-6, 1988.

[16] T. A. Van Dijk, "Discourse analysis: Its development and application to the structure of news," J. Commun., vol. 33, no. 2, pp. 20-43, 1983.

[17] T. A. Van Dijk, "Media contents The interdisciplinary study of news as discourse," in 
A handbook of qualitative methodologies for mass communication research, Routledge, 2002, pp. 122-134.

[18] J. C. Rowe, Post-Nationalist American Studies. Univ of California Press, 2000.

[19] L. H. Brown and K. S. Beckett, "Chapter 5: Separate African American schools: Giving voice to silenced communities," Counterpoints, vol. 309, pp. 67-79, 2007.

[20] D. S. Massey and N. A. Denton, "Hypersegregation in US metropolitan areas: Black and Hispanic segregation along five dimensions," Demography, vol. 26, no. 3, pp. 373-391, 1989.

[21] L. M. Center, "Ethnic diversity grows, neighborhood integration lags behind," Lewis Mumford Cent. Comp. Urban Reg. Res. Univ. Albany, 2001.

[22] "The Uncomfortable Truth : Racism, Injustice, and Poverty in New Jersey" - A Call to Action-. Anti-Poverty Network of New Jersey," 2017. [Online]. Available: http://www.antipovertynetwork.org/resources/Documents/The Uncomfortable Truth Final - web.pdf.

[23] "Newark Public School Summaries Fall 2017." [Online]. Available: http://www.nps.k12.nj.us/departments/data-research/school-summaries.

[24] P. Wall, "Racial Tensions Flare at Newark's Elite Science Park High School Amid Debate over Admissions Policies," 2018. [Online]. Available: https://www.chalkbeat.org/posts/newark/2018/04/25/racial-tensions-flare-at-newarkselite-science-park-high-school-amid-debate-over-admissions-policies.

[25] T. . Woolston, G., Panico, R \& Haydon, "State to Answer Lawsuit Seeking to Integrate NJ Schools by Friday. Retrieved from Tap into Newark," 2018.

[26] M. S. Sidney, Urban Slums Report: The Case of Newark. USA: University College London.

[27] T. J. Starr, "Newark Mayor to Trump: Forget the Wall! Our City's Water Has 'Dangerously High' Levels of Lead," 2019. [Online]. Available: https://www.theroot.com/newark-mayor-to-trump-forget-the-wall-our-citys-water1831779497.

[28] "New Jersey Environmental Justice Alliance."

Brodsky, S .: "When Lead Affects Learning”. April 9, 2016. http:// theatlantic.com/amp/article/477567. (2016) 